\title{
THE RADICAL RIGHT AND THE CRISIS OF CONSERVATISM BEFORE THE FIRST WORLD WAR
}

\author{
ALAN SYKES \\ University of St Andrews
}

The study of the Edwardian Conservative party is rapidly becoming as much of a minefield as that of the Edwardian Liberal party. Both parties were in serious difficulties in the years immediately preceding the First World War. But whilst the condition of the Liberal party is at least openly acknowledged as a disputed area, its perils clearly marked, the condition of the Conservative party is treacherous ground, the hazards uncharted. From one point of view, 'it would be easy to give an account of Edwardian politics in which the emphasis fell on "the crisis of Conservatism" and on the parlous state of the Conservative party on the eve of the War... The fundamental weakness of the Conservative party lay in its inability to win elections.' ${ }^{1}$ Alternatively, 'Both at the local-government level and in national by-elections in 1912 and 1913 , what was at work was not so much "The Strange Death of Liberal England" as "The Strange Revival of Tory England". The most likely outcome, moreover, was not apocalyptic, merely a Conservative triumph in the general election scheduled for I 915 . $^{2}$ By a curious coincidence, or perhaps editorial perversity, these two views are juxtaposed on consecutive pages of the same collection of essays.

The electoral performance of the Conservative party is, however, only an aspect of the 'crisis of Conservatism', a cause of the crisis, but not the crisis itself. That crisis, at once ideological and institutional, was precipitated by the emergence on the right of the party of groups which distrusted, and in 191 I defied, the official party leadership which they thought had proved ineffectual in preventing steady national decline: 'It was thus in a mood of despairing rage that many Conservatives watched their beloved country sliding to disaster (or so they believed), while the opposition proved itself powerless to persuade the electorate of the dangerous situation in which it had been placed by an irresponsible radical ministry. ${ }^{3}$ Despite Balfour's resignation in $19 \mathrm{I} \mathbf{I}$, these groups remained frustrated in their attempts to influence national policy by traditional means. Their disaffection widened to embrace not just the Conservative leadership, but apparently the party and the party system in its

G. R. Searle, 'Critics of Edwardian society: the case of the radical right', in Alan O'Day (ed.), The Edwordian age: conflict and stability (1979), p. 79

- Walter L. Arnstein, 'Edwardian politics: turbulent spring or Indian summer?', ibid. p. $7^{8 .}$

' G. R. Searle, 'Critics', p. 80. 
entirety. They were a force to be reckoned with. The moderates of both front benches were unable to prevent either the polarization of political life embittered by the Home Rule controversy, or the drift towards violence, whether from Ireland, or from syndicalists and suffragettes in the streets. Unable to control events, they were accordingly unable to control their parties. 'This vital center had more or less resigned itself before the war to a spectator's role, awaiting the fatal conflict between the political extremes.' As an indication of a crisis of Conservatism, as distinct from a crisis of Liberalism, this presentation has its weaknesses. Public disorder was a problem of government, not of opposition. Gun-running in Ireland, Ulster intransigence, labour and suffragette unrest, in so far as they were manifestations of the government's incompetence and the bankruptcy of its policies, worked to the Conservatives' advantage, and were the very factors that would make for a Conservative victory at the next election. They became part of a 'crisis of Conservatism' only to the extent that the critics of the party's leadership became impatient for an election, doubted its outcome, or doubted their leaders' willingness to implement their policies in the event of success.

As G. R. Searle rightly points out, 'the stratification of the right was complex, and made more so by individuals who shifted their stance or moved from one group to another...'. Nevertheless, some broad agreement has emerged that the right consisted of three groups: the traditional Conservatives of moderate, Balfourite views; a 'Milnerite' group of 'social-imperialists, advocates of 'national efficiency', who sought some form of national government above party politics, and welcomed Lloyd George's coalition proposals of 1910 and his experiments with social reform such as the Insurance Act; and the 'radical right' or 'radical tories', basically an extension of the 'diehards', inspired by Willoughby de Broke and Leo Maxse, editor of the National Review, with sympathetic noises from disaffected Liberals, notably Arnold White and the Belloc-Chesterton circle. ${ }^{5}$

The distinctions between the first, traditional Conservative, group and the second, social-imperialist, group are generally clear. Balfour's hesitation on tariff reform and his rejection of related 'constructive policies' need no further elaboration here, nor do the criticisms directed at his leadership by frustrated tariff reformers. Contemporaries were well aware of these distinctions. More to the point, they were also aware that they constituted not simply disagreements about details of policy and tactics, but more deeply opposed approaches to politics in general. Salisbury thus condemned the tariff reform movement not because it advocated the imposition of tariffs, but because of its lack of moderation. ' 'Milnerism', he thought, involved 'a complete change of method

4 Robert J. Scally, The origins of the Lloyd George coalition : the politits of social imperialism, $1900-1918$ (1975), p. 19.

${ }_{5}$ The distinguishing features of these groups are given more fully in Searle, 'Critics', pp. 82-4. For the 'social-imperialists', see Scally, Origins, where they are distinguished from both the traditional Conservatives and the diehards. For 'radical toryism' see Gregory D. Phillips, 'Lord Willoughby de Broke and the politics of radical toryism, 1909-1914,' Journal of British Studies xx, I (1980), 205-24.

- Salisbury to Selborne, 25 Feb. I 9o6, Selborne papers, 5, fos. 128-37. 
in our Government from the English system to the German system: from freedom to compulsion." Milner did not 'believe in freedom', and his methods might produce a revolution. 'In the old days... Conservative governments did not propose drastic legislation. But under the Chamberlain school of thought, that characteristic is seriously threatened. ${ }^{\prime 8}$ St Loe Strachey scented the hated 'Jacobin' enemy in the attitudes of both Milner and Chamberlain,' and curiously the Chamberlains themselves recognized the peculiarity of their political outlook, that of the 'Radical Autoritaire'.10 By I9I I, traditional Conservatives might no longer believe, as Pembroke had written in I906, that 'Arthur Balfour is ... the best leader of the House of Commons... that we have ever had...'11 but this did not mean that they had overcome their distrust of Chamberlain or those who shared his attitudes. Iwan-Muller's rebuke to Leo Maxse still held good; 'What it seems to me you ignore is that the Tory party is not a Liberal-Radical-Unionist party. Sometimes I doubt if you believe in the existence of a Tory party at all. ${ }^{12}$

None of this clarity exists when attempting to distinguish between the 'radical right' and either the 'traditional Conservatives' on the one hand, or the 'social-imperialists' on the other. Current presentation, however, places the 'radical right' substantially closer to the latter than to the former. Both groups were bitterly critical of Balfour; Milner supported the Diehards whom Amery assisted Willoughby de Broke to organize, and the Halsbury club, as the permanent incorporation of the diehard spirit, was explicitly formed to promote 'forward' or 'constructive' policies. The club did not have the wholehearted support of Milner, who was still toying with the idea of a federal solution to Home Rule, but by 1914 even that disagreement appeared to have been forgotten as Milner, Amery and Willoughby de Broke co-operated in the British League for the Support of Ulster and the Union. In general terms, both groups identified similar problems, especially national security and social cohesion, and advocated similar solutions - for the former, national service, a large navy and imperial unity; for the latter, social reform on the basis of 'national efficiency' rather than humanitarianism. For both, tariff reform was the means to these various ends.

But even in so generalized a statement of policies differences emerged. Lord Hugh Cecil was a diehard and a violent opponent of Home Rule, but a free trader doubtful of the need for further social reform; Milner's reservations about Ireland have already been noted; both Milner and Amery believed that

' Salisbury to Selborne, 26 May I 908, Selborne papers, 5, fos. 207-1 2.

- Salisbury to Selborne, i Nov. 1910 , Selborne papers, 6, fos. 339.

- On Milner, Strachey to Margot Asquith, 5 July 1907, Strachey papers, S/11/7/16; on Chamberlain, copy, Strachey to Rosebery, 26 April 1910, Strachey papers, S/12/7/21. For Jacobinism as an even greater enemy than socialism, see Lord Hugh Cecil, Conservatism (1911), Pp. $247-8$.

10 Sir Austen Chamberlain, Politics from inside (1936), p. 81.

11 Pembroke to Douglas, 5 Feb. 1906, in Viscount Chilston, Chief whip: the life and times of Aretas Aters-Douglas, first Viscount Chilston, (1961), p. 354.

12 E. B. Iwan-Muller to Maxse, 4 Jan. 1906, Maxse papers, p. $4^{6} 4$. 
tariff reform was essential to the preservation of the Union, whereas the bulk of the Unionist party, including all but a very few of its tariff reform wing, believed that tariff reform endangered the Union, and in effect discarded the former for the sake of the latter in January I $9{ }^{1} 3$. Amongst these were Carson and F. E. Smith, both considered in other circumstances to be 'social imperialists'.$^{13}$ In one respect, the salient characteristic of the Edwardian right was its confusion. At another level, however, these policies were reflexions of different values. Lord Hugh Cecil was a free trader not only on economic grounds, but because he placed a high value on individual liberty and responsibility. In common with other Unionist free traders he feared that tariff reform policies would lead to the corruption of political life, creeping socialism in the form of government intervention, excessive taxation and the demoralization of the working classes. At the other extreme, Milner was a tariff reformer because he believed in the organization of the empire and the state, however much this involved government regulation of the individual. His disregard for liberty, which Salisbury sensed, set him apart from traditional Conservatives with traditional values. To a considerable degree it also cut him off from Willoughby de Broke.

The rehabilitation, if such it can be called, of Willoughby de Broke has been going on for some time since Dangerfield first described him as 'not more than two hundred years behind his time'. ${ }^{14}$ In $1965 \mathrm{~J}$. R. Jones saw him as 'a forceful, thoughtful and intelligent writer, an excellent Parliamentarian and a useful organiser. ${ }^{15}$ Just recently he has been portrayed as one of the leading figures of the 'radical right' and 'radical toryism'. Indeed, although other names come to mind, particularly Selborne, Maxse and George Wyndham, the existence of 'radical toryism' and of a distinctive 'radical right' within the Conservative party seems to depend almost entirely upon Willoughby de Broke and his ideas. ${ }^{16}$ In view of the clear differences between the 'social-imperialist' and 'traditional conservative' groups, it is in the attitudes and strength of the 'radical right', and in particular the attitudes of the 'aristocratic faction' of that movement, ${ }^{17}$ that any assessment of the nature and depth of the 'crisis of Conservatism' is to be found. Yet the identification of Willoughby de Broke as a radical of any kind depends upon a particular interpretation of his views which maintains that they were not what they seem. 'The paradox of the situation was that, although purporting to act as the custodians of Conservative principles, diehard leaders, such as Willoughby de Broke, in fact had a highly ambivalent attitude to the Conservative party, and were already engaged in an analysis of the political system that was to put them some way outside the

13 R. J. Scally, Origins, pp. I1 (Carson), and 213-15 (Smith). As early as 191 I, H. A. Gwynne feared that 'the Halsbury Club might stifle tariff reform': Sir Austen Chamberlain, Politics, p. 364 .

14 G. Dangerfield, The strange death of Liberal England (1936), p. 42.

15 J. R. Jones, 'England' in Hans Rogger and Eugen Weber (eds.), The European Right, (1965), pp. 43-4.

16 See Searle, 'Critics', and Phillips, 'Willoughby de Broke'.

12 The term is Searle's: 'Critics', p. 95. 
pale of Conservatism, as that creed is usually understood. ${ }^{18}$ This is too simple. British Conservatism, as the political creed of an active political party, is peculiarly difficult to define in the abstract, and the factionalism of Edwardian politics does not simplify the task. One of the most recent, and most successful, attempts to codify conservative doctrine thus notes that 'its essence is inarticulate... The awareness that conservatism has no universal purpose definable for all peoples and for all times, has led to a tradition among English conservatives according to which their beliefs are essentially unsystematic, distrustful of theory, practical, empirical and day-to-day. ${ }^{19}$

What can be said about the British right is that it has evolved with two different, even conflicting, traditions, which exist in varying degrees of tension within a single political party, and even within individuals. These traditions have been described in various ways, as the difference between Peel and Disraeli, ${ }^{20}$ between small ' $c$ ' and large ' $C$ ' conservatism, or between empirical and intuitive conservatism. Essentially the difference is between a rationalist approach, seeking the greatest happiness of the greatest number in a society in which anarchy is just below the surface and authority is needed to preserve any happiness at all, and a 'divine' view, in which the actual social and political order is seen as part of a larger supernatural order. The third marquess of Salisbury fell into the former category, which was very much a Cecilian tradition. ${ }^{21}$ Willoughby de Broke with his insistence on the connexion between religion and politics and the divine sanction of certain aspects of the social order falls fairly straightforwardly into the second. Rather than endure the complications of empiricism and intuition, or the size of the ' $\mathrm{C}$ ', it is simpler to acknowledge, as contemporaries did, a distinction between conservatism and toryism at the theoretical level. 'Radical toryism' is presumably something more. As applied to Willoughby de Broke, the term denotes a certain political style. His aims, according to Dr Phillips, remained 'those of a traditional landed aristocrat', but 'his methods and emphases strongly prefigured those of later rightist politicians, both British and Continental'.22 By 1914, however, the passions aroused by the Home Rule Bill were such that this criterion could embrace the bulk of the Unionist party, including, after his speech at Blenheim, the leader, Bonar Law, and, by his tactics in shouting down Asquith in the House of Commons, Lord Hugh Cecil. On the other hand, the backroom radicals, Maurice Woods and the Unionist Social Reform Committee, or the Milnerite 'kindergarten' of the Round Table movement, would be excluded by their reliance on intellectual persuasion.

At first sight, moreover, there is more radicalism in Willoughby de Broke's politics than simply 'methods and emphases'. His primary purpose, both behind the scenes and in his writings, was to expound what he believed were

18 Ibid. p. 84 .

19 Roger Scruton, The meaning of Conservatism (1980), pp. I and 193.

20 J. R. Jones, 'England', p. 3o.

21 For a discussion see M. Pinto-Duschinksy, The political thought of Lord Salisbury, $1854-1868$ (1967), pp. $54-9$.

22 Phillips, 'Willoughby de Broke', p. 205. 
the basic principles of toryism, ${ }^{23}$ and to bring the party back to these principles which he considered had been compromised during the greater part of Balfour's leadership. In so doing he introduced an element of redefinition, or more strictly rephrasing, of traditional tory concerns, putting them in the new fashionable language of social imperialism, national efficiency and 'race regeneration'.

We are pledged to reconstruct the Constitution, the Navy and the Tariff. In other branches of National life the whole field is open to us. Eugenics and Education, in fact the whole vast problem of Heredity and Environment, have got to be faced if we would keep our place among the nations. Let us rely on the National character, and aim at preserving it by breeding from the best stocks and bringing to maturity the greatest possible number of mentally and physically sound men and women, reared among healthy surroundings in the ideals of Religion and Patriotism, equipped with a trade education, protected by a Tariff from unfair foreign competition, trained to bear arms if need be for their country, admitted to all the privileges, and alive to all the duties of Membership of the British Empire. ${ }^{24}$

At times he became almost specific, as when denouncing sweated labour: 'Justice as well as humanity and patriotism demands that anyone who is ready to work bravely and honestly shall have a living wage and a healthy home', ${ }^{25}$ but such occasions were rare, and detailed proposals for implementing such ideals rarer still. His main concern was that the party should follow the right general principles, those of toryism, 'by taking up the question of the improvement of the condition of the people', and not become enmeshed in 'exclusive Conservatism'. 'The whole history and teaching of the Tory party is packed with constructive Social Reform... In industrial matters we have only to return to first principles, and preach them earnestly in relation to modern conditions. ${ }^{28}$ Hence whilst his acceptance of the role of the state in 'race regeneration' distinguished him from free trade individualists like Lord Hugh Cecil, St Loe Strachey or Cromer, Willoughby de Broke's interventionist policies were always set within the framework of traditional tory principles and values. These, in turn, limited the scope of his proposals both ideologically and in practice.

According to Willoughby de Broke, tory principles were 'of two kinds. The first is eternal, dogmatic and confirmed by Divine authority as well as by experience: of such is the inalienable right to private property... The second kind ... are not dogmatic in their origin, and some of them might be susceptible of being altered or modified in view of circumstances, though they are much more than mere expedients. But the time to alter them is not yet. ${ }^{27}$ These included the maintenance of the religious establishment, government by king, lords and commons, and a strong second chamber. Such principles left little scope for radical adventures, despite the rhetoric of social imperialism. In

23 For example, 'The tory tradition', National Review, Lvill (344), Oct. I9I I.

24 Ibid. p. 211.

25 'National toryism', National Review, LIX (35I), May 1912, pp. 419, 423.

26 'The tory tradition', p. 2 I I.

27 'National toryism', p. 419. 
practice Willoughby de Broke tended to oppose even those proposals that found favour with other sections of the right. Thus, education and the Insurance Act were both causes dear to the hearts of social-imperialists. But on the former, Willoughby de Broke saw no need to go 'beyond the elements of education'. ${ }^{28}$ His ideal worker was an illiterate labourer who, at the age of 69 , still rose at 5.30, walked two miles to work, and was 'always the first to arrive and the last to leave'. ${ }^{29}$ These were solid traditional virtues, but were hardly in keeping with the social-imperialist desire to create a technically educated labour force capable of meeting the foreign challenge. But compulsory education beyond this minimum point Willoughby de Broke regarded as 'a gross violation of freedom ', ${ }^{30}$ the sharp end of a wedge of government interference with the rights of parents. He implicitly promised to repeal the Insurance Act for similar reasons, in contrast to the social-imperialists who wished to make it a non-party measure, and he supported smallholdings only as a means to make tariff reform popular in rural areas, ${ }^{31}$ in contrast to Milner who desired the creation of a property-owning democracy for political reasons. ${ }^{32}$ Finally, he also opposed the payment of M.P.s for the traditional reason that state service of this kind was a duty and privilege that should be performed without payment, ignoring both the difficulties that non-payment created for working-class representation and the tactical problems that resulted from giving the party an anti-working-class image. His statement that 'representation should be justly balanced ${ }^{\mathbf{3 3}}$ was not only a traditional conservative point of view, it also indicated that he did not think in class terms.

In fact, although aware of the need for social reform, Willoughby de Broke saw social problems in moral rather than material terms. Rather than poverty, he regarded idleness as the major social evil of the day, idleness, moreover, of the rich as much as the poor. ${ }^{34} \mathrm{He}$ was scathing in his criticism of the new rich, and their failure to undertake public responsibilities or to provide traditional leadership in county society as a natural duty of wealth. His opposition to the payment of members was counterbalanced by the introduction in 1914 of a Territorial Forces Amendment Bill based upon the 'idea that certain comfortable and privileged people should lead the way in matters of military training'. The Bill provided that public schoolboys, university graduates, those entering the professions and anyone enjoying an income of over $£ 400$ a year should before entering upon their careers be compelled to undergo military training: 'those who cannot serve will have to pay. Those who will not serve will be put in prison, or lose their votes, or perhaps both.' The Bill was not supported by the National Service League, although Willoughby de Broke hoped that it would be the forerunner of universal service. But his principal motive was to embody noblesse oblige in legislation. He found Lord Lucas's view 'that the primary object for which any man desires to accumulate wealth is

28 Ibid. p. 423.

29 Ibid. pp. $421-2$.

so Ibid. p. 423 .

31 Willoughby de Broke to Maxse, i I June 1912 , Maxse papers 466 .

32 Milner's land memorandum, Milner papers, Box 101.

3s 'National toryism', Pp. 422-3.

34 Ibid. p. 421 . 
to be able to obtain certain privileges' - in sum, not working whether to support himself, his family, or the state, 'amazing'.

Criticism of the rich, particularly the industrial and commercial rich, was widespread, but not universal, ${ }^{35}$ among the right, ranging from Maxse's Radical Plutocracy Enquiry in the National Review to Wyndham's comments on 'oriental financiers' and Garvin's 'Plunderbund'. In introducing the land taxes in 1909, and subsequently launching the 'land campaign', whilst being supported by wealthy men, whose wealth was not primarily landed, the Liberal government left itself open to this kind of attack. Moreover it was a legitimate defence by the landed interest that believed itself singled out for punitive taxation for political reasons. But for Willoughby de Broke at least, it was not an attack upon the rich because they were rich, but because they were not behaving as the rich should - serving as J.P.s, contributing to local charities, providing hospitality, and if necessary running estates at a loss, contributing to the foxhounds - all the multiplicity of local functions and duties performed by the squire in traditional county society. 'There is no one capable of greater arrogance and selfishness', he wrote to Leo Maxse,

than certain people who give as little as they dare to the foxhounds; from which they derive the whole of their society and amusement, while spending every other shilling they have on comforts and luxe of all kinds. These are the poeple who take no interest in public life and who we want to catch and dub (and will too) when our compulsory service takes effect. ${ }^{36}$

Some venom was perhaps added to these feelings by an awareness that the landed interest had already lost its pre-eminence. In the debate, Ampthill sourly explained his opposition to Willoughby de Broke's Bill on the grounds that 'the duty of National Defence has always been the privilege and honour of the governing classes. The Masses now form the governing class; they must therefore take on this duty and privilege.' But in general, noblesse oblige remained a traditional Tory sentiment. ${ }^{37}$

Despite his strong support for tariff reform, Willoughby de Broke's attitudes to the constructive policies which were so marked a feature of tariff reform agitation were thus to say the least ambivalent. On the one hand a leader of the 'Reveille' movement, with its sophisticated programme of 'Unionism', he could also write that 'the idea of the programme is entirely foreign to the British conception of politics'. ${ }^{38}$ Basically, he had little faith in legislation.

It is not so much by passing laws as by reconstructing thought that Unionism can succeed to-day... The leaders of the Unionist party have a unique opportunity of saving the nation by leading a confused and discordant public mind back to first principles, by applying these principles to modern conditions so as to give a sure and certain

${ }^{36}$ For example G. R. Lane Fox to Maxse, 30 Oct. 1912, Maxse papers 467 .

so Willoughby de Broke to Maxse, 4 Jan. 1909, Maxse papers 445 .

37 For this paragraph see Willoughby de Broke, 'The comfortable classes and national defence', National Review, LXIII (375), May I914, Pp. 428-42.

s8 Willoughby de Broke, 'The restoration of the constitution', National Review, LVuI, (348), Feb. 1912, p. 857 . 
message of hope, and by making the Unionist party the vehicle of a great national revival, intellectual, spiritual, material. ${ }^{39}$

In this respect Willoughby de Broke was closer to the so-called 'stylized toryism' of the party of Disraeli and the Cecils' ${ }^{\prime 40}$ than has been recognized, perhaps because tariff reform criticism of this 'stylized toryism' has been taken too much at its face value. In reality traditional conservatism was flexible and pragmatic in its approach to tariff and social reform. Thus Balfour, whatever his innermost reservations, had no 'right and wrong' convictions on tariff reform, but approached it from a purely tactical point of view, as did Salisbury. ${ }^{41}$ Salisbury, although not typical because of his privileged position in high politics, and his clarity of mind, nevertheless voiced many of the concerns of traditional conservatism during the Edwardian period. Far from being 'stylized', he showed a continual willingness to consider innovation with an open mind, within the flexible restraints of empirical conservatism. He accepted, for example, Selborne's criticism that in the light of working-class unrest the Unionist party had a duty to solve the problem of unemployment, ${ }^{42}$ and even anticipated the question. ${ }^{43} \mathrm{He}$ therefore turned to the problem of devising a conservative social policy which while avoiding 'public alms-giving in any form to the working classes', might use 'the machinery of the state to help any efforts of their own' such as using the post office as an unemployment bureau, ${ }^{44}$ contributory old age pensions, and state-organized insurance against periods of unemployment. By I 9 I 2 he had come to accept the principle of the legislative minimum wage and, whilst prepared to pass the government's proposals in the lords because of the emergency, condemned them as insufficiently scientific. His own ideas centred around some form of state interference to guarantee wages in return for a prohibition of strikes in vital industries such as coal and transport. ${ }^{45}$ These were, however, essentially palliatives, which would not remove the source of the difficulties. Like Willoughby de Broke, Salisbury thought in moral rather than material terms:

the social system is out of joint; the dumb misery of the very poor is heart-rending, competition is often very cruel, and political economy provides no remedy. The reason is that the malady is not economical or political but moral. The vice of the poor, the selfishness of the rich, the hardness of the middle-classes are moral evils and must be combatted by moral weapons... The solution is beyond the sphere of politicians. ${ }^{46}$

There is also considerable similarity between the tactical assessments of

* 'National toryism', p. $4^{18}$.

40 R. J. Scally, Origins, p. 221.

11 Salisbury to Selborne, 15 Nov. 1907 , Selborne papers, 5, fos. $205^{-6 .}$

is Copy, Selborne to Salisbury, 2 I April 1907, Selborne papers, 5, fos. 183-4.

4 See Salisbury's comments on the working class after the Colne Valley election: '... it is a vague discontent with existing social circumstances. They do the work, but they bear the brunt of all the bad times. . They would vote for anything which gives them security. But they are not to be seduced by vague phrases. It must be definite proposals for their welfare.' Salisbury to Selborne, $27 \mathrm{July} 1907$, Selborne papers, 5 , fos. $170-3$.

4 Salisbury to Selborne, 26 Sept. 1907, Selborne papers, 5, fos. $189-94$.

* Salisbury to Selborne, ro April 191 2, Selborne papers, 6, fos. 126-31.

* Salisbury to Selborne, 3 Oct. 1907, Selborne papers, 5, fos. 195-202. 
Willoughby de Broke and Salisbury which set them apart, as traditionalists within a libertarian tradition, from the social-imperialist school of thought. Thus, despite his strong support for compulsory national service, and somewhat inconsistently, Willoughby de Broke was well aware of popular hostility to compulsion. He specifically linked his criticisms of the educational system to the loss of income it involved for parents deprived of their children's potential earnings, ${ }^{47}$ and even more explicitly noted that 'the vast mass of the people loathe and detest the whole system of compulsion and will vote for any party who will abolish it', by repealing the Insurance Act. ${ }^{48}$ Salisbury in turn explained his opposition to national service on the grounds of popular hostility to compulsion. ${ }^{49}$ More generally, Unionists of all complexions identified the same tactical problem after the 1906 general election - the loss of working-class support. They explained their defeat in these terms, rather than as the result of their own divisions or the backlash of Liberals aggrieved by the Education Act and tariff reform, and made the avoidance of a confrontation with labour the basis of their tactics in the house of lords from the Trades Disputes Act in 1906 to the minimum wage legislation of 1912 . While most noticeable among the tariff reform wing, this concern to regain working-class support was common to all sections of the party. 'Unless we can do something to reconcile the working classes to the Unionist party,' Salisbury thus wrote in 1907 , 'then the controversy between the Government and the House of Lords can only end in one way. ${ }^{50}$

Where Salisbury and the tariff reformers differed was in the way to win back this support. Whilst the tariff reformers, at least until I 1 I I , believed that tariff reform was all that the working class 'really cared about', ${ }^{51}$ and would outweigh their lack of interest in traditional conservative causes, Salisbury feared that the unpopularity of the 'food tax' would drag down the party, the lords, the church and the Union. By and large the party had shifted to accept this tactical argument by 1913. This did not preclude sympathy with the objectives of tariff reform, either domestically, or imperially. 'Preference,' Salisbury thought, 'if it be possible without estranging any considerable section of the British working class would... do good; but I cannot conceive that it would be wise to build consolidation of the Empire upon a policy which would be susceptible of reversal at a succeeding general election. An Imperial policy must be practically agreed by all parties within the state. ${ }^{52}$ As early as 1905 he was attempting to devise a scheme of preference that would avoid food taxes, ${ }^{53}$ a policy to which Derby was to return in ${ }^{1} 912$. The reasoning behind

47 'National toryism', p. 423.

4B Willoughby de Broke, 'The Unionist party and the general election', National Review, Lxu (377), July 1914, p. 785 .

40 Salisbury to Selborne, 26 May 1908, Selborne papers, 5, fos. 207-12.

50 Salisbury to Selborne, 26 April, 1907 , Selborne papers, 5, fos. $150-7$.

51 Willoughby de Broke to Maxse, 2 I March I909, in Phillips, 'Willoughby de Broke', p. 206. See also Sir Austen Chamberlain, Politics, pp. I96-8 and Law to Sandars, 29 Nov. 1910, Balfour papers, $49^{6} 73$, fos. 6-8.

52 Salisbury to Selborne, 26 April 1907 , Selborne papers, 5, fos. $15^{\circ}-7$.

53 Salisbury to Selborne, I Sept. 1905, Selborne papers, 5, fos. 1034 . 
the movement that built up during 1912 for dropping the 'food taxes' from the party programme was similarly tactical, as was Bonar Law's when he finally abandoned preference in 1913 .

If anything, Willoughby de Broke was more opportunist and partisan, in ordinary party terms, than Salisbury. Coming into politics as a reaction to the budget of $1909,{ }^{54}$ with its explicit attack on the landed interest, his immediate aim was to remove the government. Social reconstruction took second place to this: 'the first and foremost Reform is to get rid of the Radicals'. ${ }^{55}$ Even on the Union, his attitude was essentially tactical, based on English not Irish considerations. 'The real value of the Home Rule struggle will be to stiffen the sinews; warm up the blood, and show all the enemies of England at home and abroad that they still have to reckon with the old spirit. 56 'Diehard' resistance to the Parliament Bill in $\mathrm{I} 9 \mathrm{I} \mathrm{I}$, and 'diehard' support of Ulster in 1914 were means to the same end - to 'get rid of the Radicals'. At one time Willoughby de Broke toyed with the idea of passing the Home Rule Bill immediately, in the expectation that this would create greater difficulties for the government than resistance, but as always 'uppermost in his mind... was the question of the impact of a particular political stance on the Unionist party and the electorate' ${ }^{57}$ It was on the grounds that such partisanship would make it impossible for any one party to risk the unpopularity of introducing great national reforms - federal Home Rule, tariff reform, national service, etc. that Lloyd George justified, and the social-imperialists welcomed, coalition proposals in rgro. But however much he used their language, Willoughby de Broke never shared the centrist political outlook of the social-imperialists.

In his analysis of their Conservative support, Willoughby de Broke was also closer to Salisbury than to the social-imperialists. Paraphrasing Burke, he saw 'a disposition to preserve and an ability to improve' as the 'standard of a statesman'. But in existing circumstances, 'greater prominence should be given by the Conservative and Unionist party to a "disposition to preserve" if it is to remain a Conservative party at all... at least as many people will vote Unionist in order to conserve certain things, and to knock out Mr. George, as from a wild desire to see the Unionists try their hands on our land and social system. ${ }^{58}$ It was for such reasons - that the Conservative party was a conservative party and not a Radical-Liberal-Unionist party - that Salisbury consistently opposed the more extreme doctrines and exclusive tactics of the tariff reform wing. In their hands, tariff reform was 'an effort to drive the Conservative elements of our society into a policy of far-reaching change', ${ }^{58}$ which would alienate them because they were conservative. 'My conception of Tariff Reform is to go a step - and that only a short step - at a time...only

\footnotetext{
54 Willoughby de Broke to Mr Boutwood, 13 Nov. 1914, Willoughby de Broke papers, $W B / 11 / 3$.

sb 'The tory tradition', p. 2 I 2.

so 'National toryism', p. 417.

57 Phillips, 'Willoughby de Broke', p. 221.

s8 Willoughby de Broke, 'The Unionist position', National Review, LxII (368), Oct. 1913, p. 2 I8.

69 Salisbury to Selborne, I6 Aug. I904, Selborne papers, 5, fos. 88-91.
} 
a policy of this kind... has the least chance of real approval by the mass of the Conservative party. ${ }^{60}$

This vision of the grassroots support guided his attitude to all suggestions for reform, both social and constitutional. Selborne's idea that the party should consider Home Rule all round thus met with the same objection: '...our supporters are Conservatives. Anything like sweeping change is in fact repugnant to a large and influential proportion of them. Whatever your own opinions, the Conservative party can only assimilate change gradually. I believe the advocacy of almost any sweeping change will lose you enough votes to put you in a minority.' With this, Willoughby de Broke whole-heartedly agreed.

The ordinary Tory does not necessarily know much about Party cries and politics, and does not necessarily follow the niceties of a disputation about the details of a Referendum or a Tariff...He is guided by tradition rather than by abstract theory, by experience rather than by the spirit of the age, by instinct rather than by intellect. He usually votes for the Unionist party... because he thinks that, on the whole, that party will be the guardian of those national institutions in which are embodied his own prejudices and sentiment... He thinks that all fresh legislation is probably bad. ${ }^{61}$

The true Conservative tactics in the pre-war crisis were thus 'while holding on like grim death to our Conservative supporters to make it easy for those who are horrified at the strikes to join us. So far as our principles permit, we should leave out from our programme what repels the moderate Liberal, and we should insert what will attract the non-socialist working man. ${ }^{162}$ Such tactical considerations directed to the same end were characteristic of the Unionist party as a whole, and led them to change policy after policy, priority after priority, in the search for the right expedient. By I9I 3 intransigence appeared to offer the greatest hope of success. As a result, the party officially drew closer to the uncompromising attitude or alternatively to those first principles that Willoughby de Broke advocated.

But differences arose between Willoughby de Broke, Milner and the British League, on the one hand, and the Unionist party on the other, over how far they should go. In 1914, these differences were insignificant. Since the ends both groups had in view might be achieved by a general election, both groups could co-operate in getting the government out. Considering this policy in 1913, however, Willoughby de Broke saw no reason to abide by the results of that election, 'which may be won on some different issue', ${ }^{63}$ although what he intended in that event was left unspecified, and never put to the test. On the other hand, after Law's Blenheim speech there was also no limit on the extent to which the Unionist party officially was prepared to go, a declaration that was also never put to the test. Ireland was in many ways a special case between I9II and I9I4, as at other times, in that it introduced a degree of

\footnotetext{
${ }^{60}$ Salisbury to Selborne, ${ }_{25}$ Feb. 1906, Selborne papers, 5, fos. 1 28-37.

61 'The Unionist position', pp. $214^{-15}$.

62 Salisbury to Selborne, I 2 Sept. I9I I, Selborne papers, 5, fos. I1 $15^{-2}$ I.

${ }^{63}$ Willoughby de Broke to Law, it Sept. 1913, Law papers, 30/2/10.
} 
violence not usually associated with British parliamentary politics. Violence in Ireland, however, was (and is) perfectly compatible with normal parliamentary politics in the rest of Britain. Moreover, in 191 I the problem of extremism was a familiar one, as were the differences over it. As Balcarres, the chief whip, commented on the divisions in $19 \mathrm{I} I$, ' $i$ it is really in connection with the degree of violence employed that material differences exist between members of our party'. ${ }^{64}$

Willoughby de Broke's strictures on the party system also have to be interpreted in the light of this extreme partisanship. In the depths of his despair after the passing of the Parliament Act, whilst Balfour was still leader of the party, he briefly considered the foundation of a new party. ${ }^{65}$ But he was easily dissuaded from this action by Selborne, whose experience as chief whip of the Liberal Unionist party had shown him the difficulties. ${ }^{66}$ Similarly, in his article 'National toryism' Willoughby de Broke proclaimed that 'no one who seriously considers the state of the nation will assert that the present situation can be dealt with by a process of party politics, as we know them. On the contrary, it is this very system of party politics that has wrought so much havoc.' But the stress was on 'party politics as we know them' and 'this very system'. Willoughby de Broke did not wish, as the social-imperialists wished, to dispense with party politics in favour of a coalition, a 'menagerie of all the talents' as he called it, under 'some well-nigh forgotten politician...dug up from his obscurity...' He sought the antithesis of this, a system of party politics in which parties stood for clearly differentiated principles, in which party leaders were unable to compromise those principles and the 'collusion' of the two front benches would be impossible. His articles, particularly 'The tory tradition' and 'National toryism' were intended to state the principles of one of those parties, and to encourage adherence to them, 'to show that the Unionist Party, by becoming the champion of true Toryism' could become the 'National Party'. But party there had to be. 'There is no escape from the conclusion that nothing in this country has a real chance until it is adopted by one of the Party machines. ${ }^{267}$

Willoughby de Broke was undoubtedly more extreme in his ideas and actions than Salisbury, but he nevertheless worked within and for the Conservative party, and was in the centre of the tradition in which he placed himself - the 'tory tradition'. He attempted to define the essentially inarticulate beliefs of the 'ordinary tory' to impress them upon the party leadership, and by his intransigence to restore in the 'ordinary tory' the faith that the Unionist party would indeed defend 'those national institutions in which are embodied his own prejudices and sentiment'. To argue therefore that one of the weaknesses of the 'radical right' was the inability of 'the aristocratic faction within the

64 Balcarres to Maxse, 18 July $191 \mathrm{r}$, Maxse papers, 463 .

os Willoughby de Broke to Selborne, 17 Aug. 1911 , in Phillips, 'Willoughby de Broke', p. 215.

*e See Selborne to Wyndham, 23 Aug. Igi I, Selborne papers, 74, fos. 190-3. Selborne to Willoughby de Broke, 18 Aug. I91 I, Willoughby de Broke papers, WB/3/46.

"' 'National toryism', pp. $4^{1} 3^{-15}$. 
movement, including for instance Willoughby de Broke... to bring itself to make a clean break with the Conservative party', ${ }^{68}$ is seriously to misplace the emphasis. Willoughby de Broke was not attempting to elaborate a new creed, or a new form of political action, which might be called 'radical toryism', or 'radical right'. In so far as classification in these terms is meaningful when applied to Edwardian politicians, and this is itself doubtful, then Willoughby de Broke belongs to the category called the 'right' by Lipset, and 'resistance' by Weber, terms devised to distinguish conservatives from radicals of the right. ${ }^{60}$

Toryism existed as a doctrine ideologically distinct from but institutionally closely linked to conservatism. The distinction grew wider in the late nineteenth and early twentieth centuries, when conservatism adopted positions hitherto regarded as liberal. The prime example of this is free trade, interpreted as it was interpreted by the Unionist Free Traders to mean opposition to all forms of state intervention. In relation to this hightly conservative, or perhaps old-fashioned liberal, position, a position quite distinct from that of the traditional conservative centre of the Unionist party, the interventionist elements of toryism and the emphasis on strong government might be considered 'radical'. These interventionist traditions also had close, though superficial, affinities with the 'Social-imperialist', Milnerite outlook. But although they were dressed up in fashionable language, the values that Willoughby de Broke expressed were traditional values, and his policies were designed to preserve the position of an embattled traditional elite. In contrast the 'social-imperialists' have been described as a frustrated 'successor elite' of petit bourgeois meritocrats, amongst whom there were few members of the landed class. ${ }^{70}$ Their experts would be recruited in a far more mobile society as they replaced aristocracy with bureaucracy.

As long ago as I 975 R. J. Scally lamented 'the general absence of theoretical and ideological definitions of the various factions in the spectrum of Edwardian politics', and little has changed since then except the proliferation of labels. It is therefore possible to write of Willoughby de Broke's 'radical toryism', 'his commitment to conservatism', his dedication to 'true conservative principles', his 'reactionary values', his 'staunchly conservative goals' and his 'extreme conservatism' in the space of a single article. ${ }^{21}$ To these can be added 'social-imperialists' and 'tory-socialists', ' radical Conservatives', 'constructive tories', 'radical imperialists', 'radical Unionists', 'tory democrats', 'the radical right', and no doubt others. ${ }^{72}$ What they all have in common is the

68 G. R. Searle, 'Critics', p. 95.

60 See the discussion in Rogger and Weber, European Right, Pp. 13-16. Willoughby de Broke might possibly be classified in Weber's 'reactionary' category.

${ }^{70}$ Scally, Origins, pp. 10-1 1, 22, 26, 220.

11 Phillips, 'Willoughby de Broke',

12 'Social-imperialists' and 'tory-socialists' can be found in Scally, Origins; 'constructive tories' and 'constructive conservatives' in Jones, 'England'; the 'radical right' in Searle, 'Critics'; 'radical imperialist', 'radical Unionist' and 'tory democrat' are my own, in A. Sykes, Tariff reform in British politics (1979). 
emphasis on the extremism and the radicalism of the right and, for the most part, the radicalism of Willoughby de Broke and the diehards, thus associating them with the social-imperialists. The effect is to increase the size and influence of the Edwardian 'radical right', and give a particular slant to the nature of the support for such causes as tariff reform and 'constructive' policies. Traditional Conservatives almost disappear in a world already overrun by proto-fascists. ${ }^{73}$

There is, however, an alternative scenario, in which the 'social-imperialists' are an isolated group, a small minority incapable of operating in peacetime politics except in co-operation with the Unionist party and upon its terms, who become briefly important in the emergencies of wartime, and are summarily dismissed with the coalition which gave them prominence. Apparently similar but in reality distinct was another group, including Willoughby de Broke, and to a degree Selborne and Wyndham, who supported traditional toryism within the traditional Conservative party. Most of the time the ordinary tories for whom they claimed to speak did not distinguish between toryism and conservatism. Their support for tariff reform and similar 'constructive' measures was not because they represented some newfangled creed or a centralized bureaucracy, however much they sympathized with the vague idea of a more efficient nation and the preservation of Britain's world power. Rather, tariff reform was a step in the right direction for many for whom protection remained a cherished memory and aspiration. In the immediate context of I909-II, it also appeared to be the means to thwart Lloyd George. Frustration at their failure to halt a Liberal government apparently bent on the destruction of the landed interest by the I 909 budget and the land campaign, bent equally on the disestablishment of the Anglican church and the dismemberment of the United Kingdom, made them extreme, but it did not make them radical. ${ }^{74}$

The effect of this rearrangement of the positions of the groups within the right is to strengthen the traditionalist centre at the expense of the 'radicals', even if the Unionist party was still divided upon tactics into moderates and extremists. In reality, however, the centre was even stronger. Taking the Edwardian period, or even the period $1909-14$, as a whole leaves out the chronological dimension, at a time when attitudes were rapidly changing. Between 1909 and 191 I there was a major realignment of factions within the right, consequent upon the change of issues brought about by the rejection of the I 909 budget by the house of lords. The controversy between tariff reform and free trade, which had dominated the years between 1903 and 1909 , then gave way to the need to defend the Constitution. During 1909 and 1910 most Unionist free traders sacrificed their free trade principles to join in this defence

"Scally, Origins, p. 9; B. Semmel, Imperialism and social reform: English social and imperial thought, ${ }^{1895-1914}$ ( 1960$)$, p. 248 ; Searle, 'Critics', p. 94. The use of the term 'fascism' is usually qualified. It is a comment on the confusion that surrounds these groups and their ideas that whereas Scally and Semmel see the social-imperialists as the forerunners of fascism, Searle sees the radical right in this way.

74 Implicitly Phillips recognizes this. With his many labels, 'radical' becomes translated into 'extreme' and 'toryism' into 'conservatism'. 
alongside the more powerful tariff reformers. By the summer of igi i the centrist position of the social-imperialists and their coalitionist aspirations had also been largely destroyed. Milner, F. E. Smith, Amery and others became diehards, alongside Lord Hugh Cecil, Salisbury, Northumberland, Wyndham and Austen Chamberlain. As a result of this realignment the 'radical right' was all but swamped in a sea of traditional Conservatives defending traditional causes. Milner's virtual retirement into the more comfortable position of semi-isolation from party politics after the defeat of the diehards, left the social imperialists leaderless, while the disintegration of the radical right position continued apace. Tariff reform was central to right-wing radicalism of any variety. Yet by 1913 hardly a voice was raised in its defence. Rather, that abandonment reflected a broader shift by tariff reformers themselves away from the constructive policies that tariff reform engendered and sustained. The question of the future direction of the Unionist party had divided it for the previous decade, but by 1914 the 'crisis of Conservatism' was over. 